\title{
A new spermophagous species of Heilipus Germar from the Amazonian Region (Coleoptera, Curculionidae, Molytinae)
}

\author{
Sergio A. Vanin ${ }^{1} \&$ Fábio Gaiger ${ }^{2}$
}

\begin{abstract}
'Departamento de Zoologia, Instituto de Biociências, Universidade de São Paulo, Caixa Postal 11461, 05422-970 São Paulo-SP, Brasil. savanin@ib.usp.br

${ }^{2}$ Museu de Zoologia, Universidade de São Paulo, Caixa Postal 42594, 04299-970 São Paulo-SP, Brasil. fgaiger@ib.usp.br
\end{abstract}

\begin{abstract}
A new spermophagous species of Heilipus Germar from the Amazonian Region (Coleoptera, Curculionidae, Molytinae). Heilipus odoratus sp. nov. (type locality: Brazil, Amazonas, Manaus) is described based on adults reared from seeds of Aniba rosaeodora Ducke (Lauraceae), popularly called "pau-rosa". The species is spermophagous and develops from egg to adult inside the seeds. The new taxon is compared with the similar Heilipus draco (Fabricius, 1801). Illustrations of larva, pupa, adult and of important structures for species identification are given, including the male and female genitalia, figured for the first time for a species of Heilipus.
\end{abstract}

KEYWORDS. Heilipus, new species, "pau-rosa", spermophagy, weevils.

RESUMO. Uma nova espécie espermatófaga de Heilipus Germar da Região Amazônica (Coleoptera, Curculionidae, Molytinae). Heilipus odoratus sp. nov., (localidade tipo: Brasil,Amazonas, Manaus) é descrita com base em adultos criados em sementes de Aniba rosaedora Ducke (Lauraceae), conhecida como "pau-rosa". A espécie é espermatófaga e o ciclo de ovo a adulto transcorre no interior da semente. O táxon novo é comparado com Heilipus draco (Fabricius, 1801), espécie semelhante. Ilustrações da larva, pupa, adulto e estruturas importantes para a identificação da espécie são fornecidas, incluindo figuras das genitálias do macho e da fêmea, apresentadas pela primeira vez para uma espécie de Heilipus.

PALAVRAS-CHAVE. Espécie nova, espermatofagia, gorgulhos, Heilipus, "pau-rosa".

On July 1989, the senior author received from Mr. P.T.B. Sampaio, Manaus, a lot of seeds of "pau-rosa" infested by weevils larvae. The larvae were reared and, on November 1989, 19 adults emerged and were identified as Heilipus sp. All specimens were deposited in the insect collection of the "Museu de Zoologia, Universidade de São Paulo", São Paulo - MZSP). On May 2003, the senior author was asked by Dr. Beatriz Ronchi Teles ("Instituto Nacional de Pesquisas da Amazônia", Manaus - INPA) to identify a sample of adult weevils which larvae have been attacking the seeds of "paurosa”, Aniba rosaeodora Ducke (Lauraceae). Dr. Beatriz needed the identification to publish the results of her research on weevil predation on seeds. At once, we recognized the specimens received in 1989 and 2003 as conspecific. A closer examination of the original descriptions and of the identified material deposited in the collection of the Museu de Zoologia, Universidade de São Paulo, revealed that the species is undescribed.

When the paper was submitted to publication, five additional specimens were found by Dr. Germano H. Rosado Neto in the collection "Padre Jesus Santiago Moure (Departamento de Zoologia, Universidade Federal do Paraná - DZUP), and were incorporated into the original type-series.

The genus Heilipus was described by Germar (1824) (type species: Heilipus lactarius Germar, 1824), and came over the years do include many similar species from the New World. The genus was subsequently disassembled by Pascoe (1881), who discussed the necessity to "separate nearly allied species" and established four new genera (Arniticus, Byzes, Parabyzes and Tartarisus), by Champion (1902), who described Hilipinus, and by Sharp (1891), who described Calvertius. Many of the species originally described in Heilipus have been transfered to these six genera. Nevertheless, Blackwelder (1947) still listed 327 Heilipus species for Mexico, Central and South America. Kuschel (1955) split Heilipus again, establishing seven new genera (Haplogenus, Heilipodus, Heilus, Marshallius, Parabyzes, Placeilipus and Rhineilipus). The new taxa were described in a key to the genera of the Neotropical Hylobiini, followed by a list of the species placed in each genus. The main diagnostic characters of Heilipus (sensu Kuschel, 1955: 291) are the following: "Prementon glabrous; hind tibiae curved and forming a strong unciform mucron in the inner angle; premucron absent; mesosternal process tuberculiform". O’Brien \& Wibmer (1982) e Wibmer \& O'Brien (1986) listed, respectively, 39 species of Heilipus for North and Central America and 52 species for South America. As six species were cited in both checklists, the number of species in the New World totals 85.

\section{Heilipus odoratus sp. nov.}

(Figs. 5-13)

Type series: Holotype male (dissected) "MANAUS, AM, semente coletada em 28.VII.1989, P.T.B. Sampaio col." "Larva criada em semente de pau-rosa, Aniba roseodora, adulto em XI.1989" (MZSP). Paratypes: same data as holotype, 3 males, 6 females (MZSP); same data but "IX.1989", 3 males, 3 females (MZSP); same data but "X.1989", 

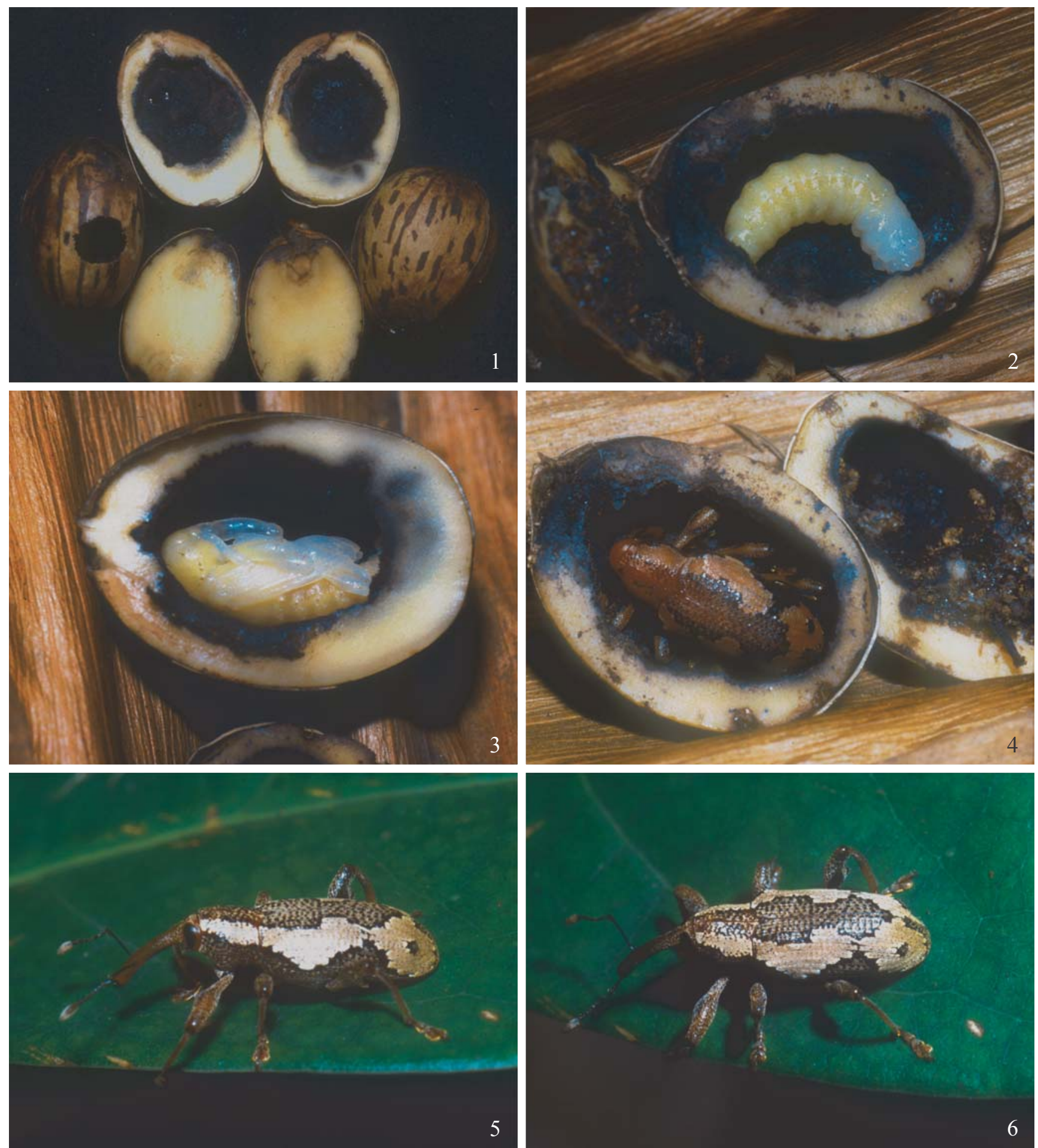

Figs. 1-6. Seeds of Aniba rosaeodora Ducke and different stages of the weevil Heilipus odoratus; 1, four seeds, from left to right, clockwise: unbroken; broken and eaten by larva; unbroken, showing circular exit orifice of adult weevil; broken, showing endosperm not damaged; 2, larva inside half seed; 3, pupa inside half seed; 4, teneral adult inside half seed; 5-6, adults of $H$. odoratus, dorso-lateral and dorsal views, respectively. Figures not in the same scale.

2 males, 1 female (MZSP); Manaus-AM, 15.V.1992, P.T.B. Sampaio leg", "coletado em sementes de pau-rosa, emergiu em 30.VI.1992" (1 female, DZUP); same data but "12.VII.1992" (1 male, DZUP); same data but "20.VII.1992" (1 male, DZUP); same data but "28.VII.1992"
(1 female, DZUP); same data but "17.VIII.1992" (1 male, DZUP); "BRASIL-AMAZONAS, Reserva-Ducke, 09-IX-01, Spironelo W." (3 males, 4 females, INPA; 1male dissected, 2 females dissected, MZSP). 

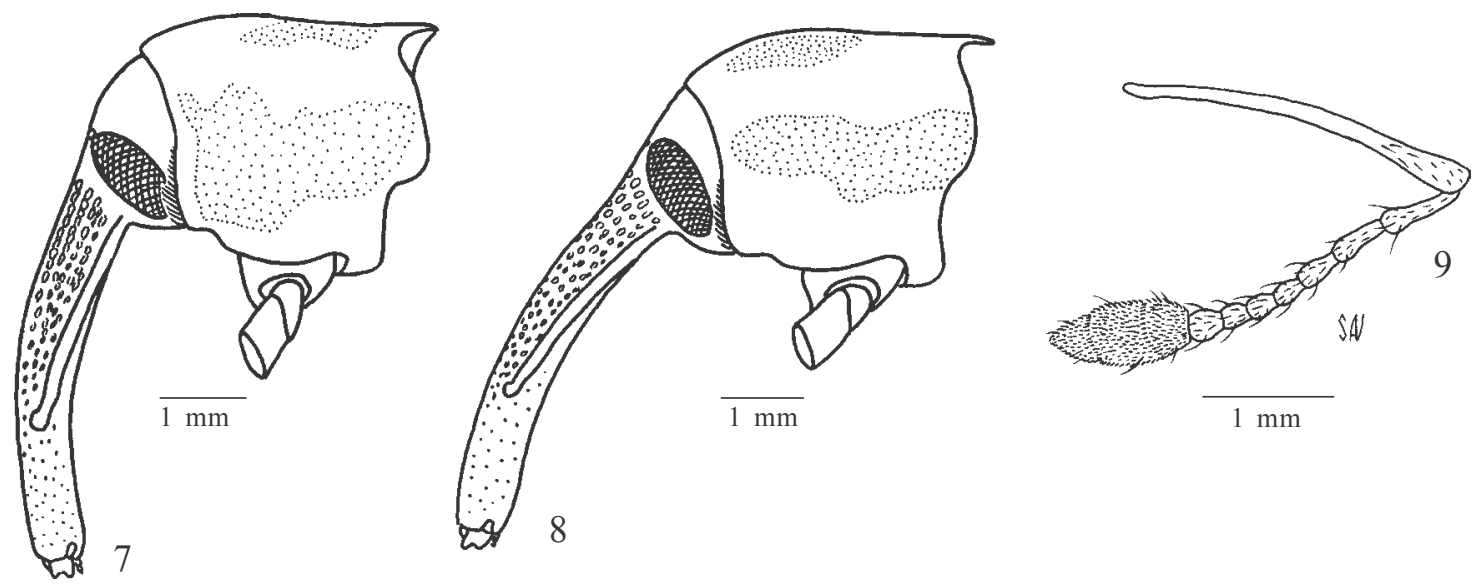

Figs. 7-9. Heilipus odoratus. 7, head and pronotum of male holotype, lateral view; 8, head and pronotum of female paratype, lateral view; 9, left antenna of male holotype.

Description of the type series. Integument subopaque, yellowish red to reddish brown, darker on sides of pronotum and elytra; antennal scape and funicle ferrugineous; femora with a dark brown spot near apex; prothorax and elytra with one stripe on each side of closely set silaceous scales, in some specimens stripes bordered by creamy scales, very irregularly indented on elytra and in some paratypes interrupted near distal third (Figs. 5 and 6).

Length (rostrum excluded), males: $10.7-12.1$; females: 9.3 $-13.5 \mathrm{~mm}$. Rostrum weakly curved, (male, Fig. 7) $1.20-1.24$ times as long as pronotum, (female, Fig. 8) 1.23-1.32 times as long as pronotum; antennal insertion pre-median, (male) 0.35 0.36 , (female) $0.38-0.40$; basal $2 / 3$ densely punctured, distal $1 /$ 3 almost smooth,with sparser and finer punctures; basal 2/3 with sparse, recumbent elongate oval silaceous scales, denser on sides; distal 1/3 glabrous. Head with sparse and shallow punctures, with elongate oval scales, denser between eyes; frons with a conspicuous deep rounded median fovea, eyes dorsally separate by distance equal to diammeter of 12 ommatidia. Antenna (Fig. 9): article I of antennal funicle (males and females) $1.45-1.63$ times as long as article II; club elongate oval, about $2.4-2.6$ times as long as wide and as long as funicular articles IV-VII together. Prothorax about as long as wide $(0.98-1.0)$, apex weakly constricted, apical margin curved, rounded at sides, widest near middle, strongly bisinuate at base, disc coarsely confluently rugosely punctate but leaving a median impunctate carina, more conspicuous and elevate at anterior half. Elytra (males and females) 2.5 -2.8 times longer and $1.5-1.6$ times wider than prothorax, $1.7-1.8$ times as long as wide, sides subparallel in basal $4 / 5$, then gradually narrowing towards apex, conjointly rounded; widest near anterior third (due to protuberant callosity on stria 9), declivital calli rounded and very prominent, almost glabrous; intervals weakly convex, slightly wider than punctures of striae, granulated wrinkled, most granules on disc transverse. Legs: femora sparsely clothed with whitish elongate scales and tibiae with scalelike setae; femora with large acute tooth; inner margin of tooth of anterior femora crenulated; inner margins of tibiae bisinuous. Venter clothed with sparse, oval, withish scales. Ventrites I and II with median depression in males, almost flat or with a shallower depression on females; ventrite $\mathrm{V}$ with apex flattened (males) or convex (females).

Male genitalia (Figs. 10 and 11): median lobe of aedeagus arcuate, slender, about 3 times as long as wide, largest width near basal fifth, sides gradually converging to pre-apical constriction, anterior margin rounded, asetose; apodemes slightly longer than median lobe; internal sac with microtrichiae but without large sclerites.

Female genitalia (Figs. 12 and 13). Sternite VIII (Fig. 12) pentagonal, anterior sides curved, apex truncate, slightly longer than wide (1.1 X), setose, membranous, only V-shaped apodeme sclerotized and darkened. Coxites short (Fig. 13), with $1 / 5$ or $1 / 6$ of the length of female rostrum; styli cylindrical, setose, articulating at apex of coxites; spermatheca (Figs 13) with capsule well sclerotized, U-shaped, branches of similar size, gland-lobe slightly larger and wider than duct-lobe; spermathecal duct very short; gland of spermatheca oblong. Bursa copulatrix without sclerites.

Sexual dimorphism weak, females on average more robust than males, and female rostrum proportionately slightly longer and slender, with weaker punctures (Figs. 7 and 8).

Etymology: odoratus, Latin, "fragrant", in reference to the hostplant, "pau-rosa" (Aniba rosaeodora Ducke), the commercial source of linalol, an essential oil used in the composition of famous perfumes.

\section{Type locality. Manaus, Amazonas, Brazil.}

Remarks. Heilipus odoratus is similar to Heilipus draco (Fabricius, 1801) $(=$ H. rectirostris Champion, 1902: pl.1, Figs. 19-19a), a species with a wide range, known from Bolivia, Brazil (Amazonian region), Paraguay, Peru, Venezuela, Central America and West Indies (Wibmer \& O'Brien, 1986). The two 

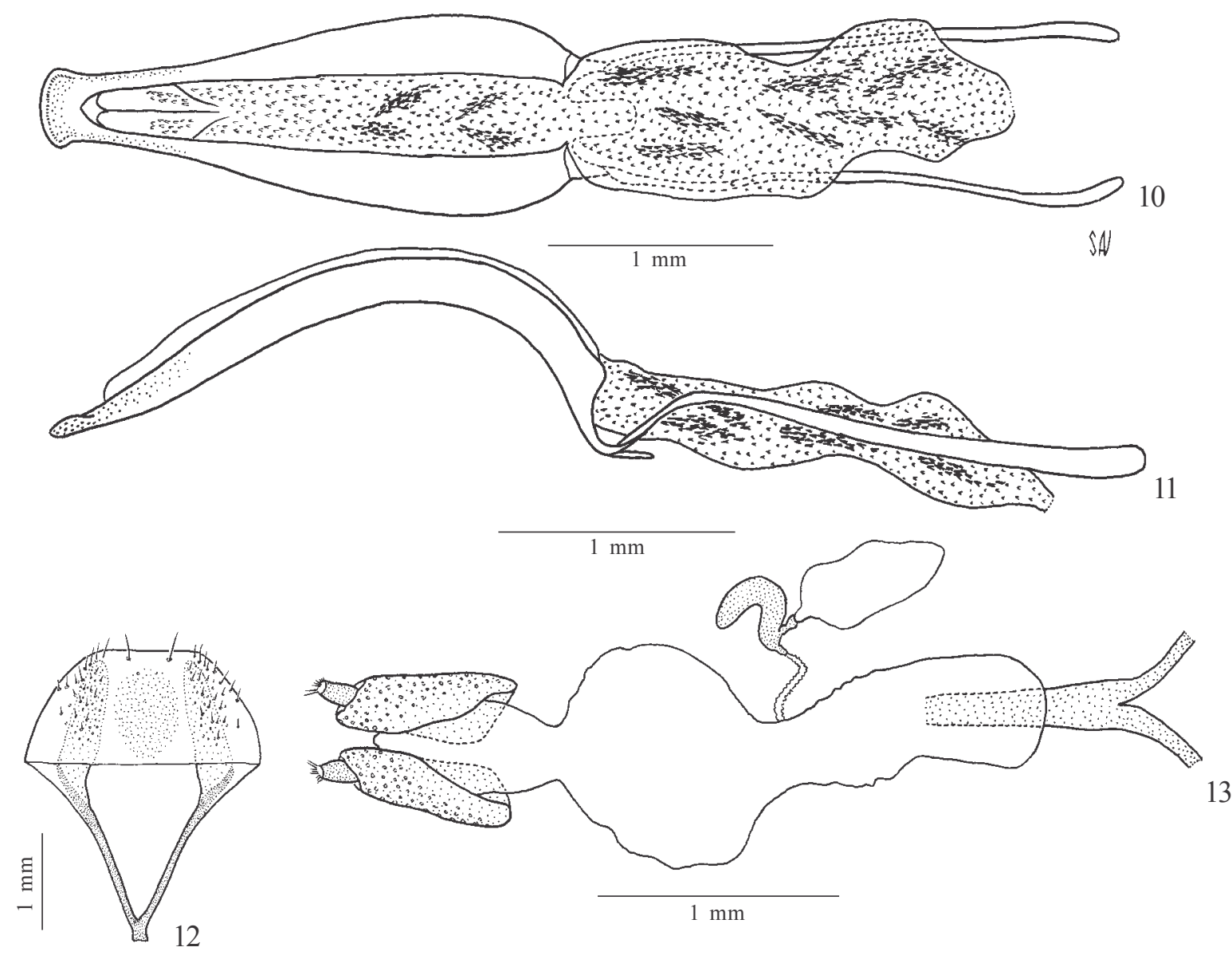

Figs. 10-13. Heilipus odoratus, aedeagus of holotype. 10, dorsal view; 11, lateral view; 12, Sternite VIII; 13, female genitalia.

species share a very similar color pattern. However, H. draco is distinguished by the body proportionately broader and shorter $(H$ draco: prothorax transverse, ca. 0.8 times as long as wide; elytra $1.5 \mathrm{X}$ as long as wide; H. odoratus: prothorax about as long as wide; elytra $1.7-1.8$ times as long as wide). Furthermore, the rostrum is weakly curved in $H$. odoratus, while is almost straight, shorter and slender in H. draco.

Geographic distribution. The new species is known only from Manaus, State of Amazonas, Brazil. Probably, the distribution of $H$. odoratus follows the range of the host-plant, Aniba rosaeodora Ducke.

Biological data. Only a summary is reported herein. A detailed account will be published elsewhere by Dr. Beatriz Ronchi Teles (INPA). Heilipus odoratus is a spermophagous species. The larva develops inside the seeds of "pau-rosa" (Aniba rosaeodora Ducke). The female oviposits directly in the seed, in a channel excavated with the rostrum. As the coxites are proportionately very short, the egg is probably laid at the entrance of the hole and the rostrum helps to push the egg deeper into the channel. We observed only one larva inside each seed (Figs. 2-4). During its development, the larva eats most of the endosperm of the single seed (Fig. 2). The pupal instar also occurs concealed inside the seed (Fig. 3). After the metamorphosis is accomplished, the adult makes a circular hole - about $6 \mathrm{~mm}$ in diameter - with the help of the mandibles, and leaves the eaten seed (Fig. 1). It is interesting to note that the thick-shelled seed represents the food resource for larva, as well as a shelter and safe site for larva, pupa and teneral adult (Figs. 2-4). Certainly, this way of life, with a sheltered endophytic development from egg to adult, results in an advantage to the weevil, less prone to starvation, predation, parasitism and desiccation (Anderson, 1995).

The seeds were collected by Sampaio in Manaus, AM, at the end of July. The adults emerged from the seeds, in our laboratory at São Paulo, SP, from September to November. Another sample of seeds, also collected at the same place by Sampaio, in May, were sent to Dr. Rosado Neto (DZUP). From the seeds emerged five adults and one parasitoid, a male Braconidae. The specimens received from Dr. Beatriz Ronchi Teles were collected in the Reserva Ducke (Manaus, AM) in the beginning of September.

Lima (1956: 101) commented on a group of Heilipus species, which have spermophagous larvae and adults with a long 
rostrum. As examples, he cited H. hopei Boheman, 1843 and an undescribed species wich develops in the seeds of "maúba" (Licaria mahuba, Lauraceae). That author (l.c.) noticed that some species of Heilipus with shorter rostrum might also be spermophagous, like $H$. montei Lima, 1935 (junior synonym of H. parvulus Boheman, 1843, according to Kuschel, 1958 and Lima, 1960). He also observed that, according to Lacordaire (1863: 458), such spermophagous species should be placed in a separate genus. In a future review of the genus Heilipus, the distribution of the spermophagous habits among the species should be considered.

Acknowledgments. Thanks are due to Mr. P.T.B. Sampaio (Manaus) and Dr. Beatriz Ronchi Teles ("Instituto Nacional de Pesquisas da Amazônia", INPA, Manaus) for making the seeds and the adult weevils accessible for study, to Dr. Germano H. Rosado Neto (Departamento de Zoologia, Universidade Federal do Paraná, Curitiba ) and Dr. Wayne C. Clark (Department of Entomology and Plant Pathology, Auburn University, Alabama) for critics and suggestions that improved the paper, and to "Fundação de Amparo à Pesquisa do Estado de São Paulo" (FAPESP) for providing the grants Proc. 2003/06542-8 and Proc. 2003/06501-0

\section{REFERENCES}

Anderson, R. S. 1995. An evolutionary perspective on diversity in Curculionoidea. Memoir of the Entomological Society of Washington 14: 103-114.

Blackwelder, R. E. 1947. Checklist of the coleopterous insects of Mexico, Central America, the West Indies, and South America.
Bulletin of the United States National Museum 185: 765925.

Champion, G. C. 1902. Biologia Centrali-Americana, Insecta. Coleoptera. Rhynchophora. Curculionidae, Curculioninae (part) 4, 144p. pls 1-8.

Germar, E. F. 1824. Insectorum species novae aut minus cognitae, descriptionibus illustratae, Coleoptera 1 , Hendel \& Sons, Hallae, xxiv $+624 p$

Kuschel, G. 1955. Nuevas sinonimias y anotaciones sobre Curculionoidea (Coleoptera). Revista Chilena de Entomologia 4: 261-312.

Kuschel, G. 1958. Neotropische Rüsselkäfer aus dem Museum G. Frey (Col. Curcul.). Entomologische Arbeiten aus dem Museum Frey. 9: 750-798.

Lacordaire, J. T. 1863. Histoire naturelle des insects. Genera des Coléoptères 6, Paris, Roret, $637 \mathrm{p}$.

Lima, A. da C. 1956. Insetos do Brasil 4 (Coleópteros), Escola Nacional de Agronomia, Rio de Janeiro, $373 \mathrm{p}$.

Lima, A. da C. 1960. Sobre alguns curculionídeos mencionados no tomo $10^{\circ}$. de "Insetos do Brasil" (1956). Revista Brasileira de Entomologia 9: 128-128.

O'Brien, C. W. \& G. J. Wibmer, 1982. Annotated checklist of the weevils (Curculionidae sensu lato) of North America, Central America, and the West Indies (Coleoptera: Curculionoidea). Memoirs of the American Entomological Institute 34: 1382.

Pascoe, F. P. 1881. On the genus Hilipus and its Neo-Tropical allies. Transactions of the Entomological Society of London 1881: 61-102, pls. 1-2.

Sharp, D. 1891. Description of a new genus and species of Rhynchophorous Coleoptera. Annals and Magazine of Natural History, ser 6, 7: 150-152.

Wibmer, G. C. C. W. \& O'Brien. 1986. Annotated checklist of the weevils (Curculionidae sensu lato) of South America (Coleoptera: Curculionoidea). Memoirs of the American Entomological Institute 39: 1-563.

Received 9.XII.2004; accepted 1.III.2005 